\title{
Population structure, growth and production of the yellow clam Mesodesma mactroides (Bivalvia: Mesodesmatidae) from a high-energy, temperate beach in northern Argentina
}

\author{
Marko Herrmann · José E. F. Alfaya • \\ Mauro L. Lepore · Pablo E. Penchaszadeh • \\ Wolf E. Arntz
}

Received: 2 August 2008/Revised: 16 August 2010/Accepted: 26 August 2010/Published online: 11 September 2010

(C) Springer-Verlag and AWI 2010

\begin{abstract}
The yellow clam Mesodesma mactroides (Bivalvia: Mesodesmatidae) was once the most abundant intertidal species on the Atlantic coast of northern Argentina and an important commercial resource in South America. This study of a population inhabiting the intertidal zone of the sheltered-dissipative sandy beach Santa Teresita documents the species' population biology, including demographic structure, growth and production during December 2004 and December 2006, and adumbrates the critical state of M. mactroides at present. A total of 3,015 M. mactroides were collected and measured, whereas individuals were found with an anterior-posterior shell length between 2 and $64 \mathrm{~mm}$. A von Bertalanffy growth function with an asymptotic length $\left(L_{\infty}\right)$ of $85 \mathrm{~mm}$ and a growth constant $(K)$ of 0.47 year $^{-1}$ was established from length-frequency distributions. The longevity of the species is estimated at approximately 6 years, and instantaneous mortality rate was about three times higher than
\end{abstract}

Communicated by H.-D. Franke.

M. Herrmann ( $\square)$

Johann Heinrich von Thünen-Institute (vTI),

Federal Research Institute for Rural Areas,

Forestry and Fisheries, Institute of Baltic Sea Fishery (OSF),

Alter Hafen Süd 2, 18069 Rostock, Germany

e-mail: marko.herrmann@gmx.de

M. Herrmann · J. E. F. Alfaya · M. L. Lepore ·

P. E. Penchaszadeh

Museo Argentino de Ciencias Naturales,

Av. Angel Gallardo $4703^{\circ}$ piso lab. 80,

C1405DJR Buenos Aires, Argentina

W. E. Arntz

Alfred Wegener Institute for Polar and Marine Research,

Section of Marine Animal Ecology, P.O. Box 120161,

27515 Bremerhaven, Germany
40 years ago. Besides, this study confirmed that the overall growth performance index $(O G P)$ is habitat-specific and can be used to group M. mactroides and M. donacium from different areas into temperate and upwelling species. Furthermore, $O G P$ is inversely correlated with the latitudinal distribution of Mesodesma populations. The intertidal biomass ranged between 0.06 and $0.07 \mathrm{~g} A F D M$ $\mathrm{m}^{-2}$ year ${ }^{-1}$. Individual production was observed to be highest at $47 \mathrm{~mm}$ length $\left(0.35 \mathrm{~g} \mathrm{AFDM} \mathrm{m}^{-2}\right.$ year $\left.^{-1}\right)$, and annual production ranged between 0.12 and $0.19 \mathrm{~g} A F D M$ $\mathrm{m}^{-2}$ year ${ }^{-1}$, resulting in productivity values $(P / B)$ between 1.84 and 2.93. The comparison of the results of the present study with those of growth studies conducted on $\mathrm{M}$. mactroides 40 years ago revealed the following considerable differences in the population structure of M. mactroides, indicating the conservation status of this intertidal bivalve as endangered: (1) present growth rates are faster, but that the maximum length attained has decreased, (2) the numbers of individuals per square metre were many times higher in the past than in the present, (3) bivalves from the present work never reached the 'commercial size' of $60 \mathrm{~mm}$ and (4) 40 years ago, the population of M. mactroides was composed of up to three cohorts, whereas in this study, there was only one single cohort visible.

Keywords Bivalves - Almeja amarilla . Population dynamics . Growth performance indices . Argentinean sandy beaches

\section{Introduction}

The world's open coastlines are dominated by almost 70\% of sandy beaches (Bascom 1964; McLachlan and Brown 2006), at which $39 \%$ of the global human population are 
living (within $100 \mathrm{~km}$ from the coast, CIESIN 2000). Exposed sandy beaches are one of the most dynamic environments, where sediment is being constantly moved by waves, winds and tides (McLachlan and Brown 2006). Previous investigations have demonstrated the influence of biological parameters (e.g. Defeo et al. 1992b; Defeo and de Alava 1995; Defeo 1996), as well as humans (e.g. Defeo 1998; Brazeiro and Defeo 1999), on the dynamics of populations and communities. However, physical parameters, mainly wave energy and particle size, are suggested as the main factors controlling the responses of the macrofaunal populations and communities (McLachlan et al. 1995, 1996). Rating systems for beach types (Short and Wright 1983) and beach exposure (McLachlan 1980) were used for a variety of previous studies investigating sandy beaches with contrasting morphodynamics (e.g. Souza and Gianuca 1995; Calliari et al. 1996; Gómez and Defeo 1999; Ricciardi and Bourget 1999; Jaramillo et al. 2000; Nel et al. 2001; Veloso and Cardoso 2001; de la Huz et al. 2002; Defeo and Martínez 2003; Laudien et al. 2003; Brazeiro 2005; Celentano and Defeo 2006; Delgado and Defeo 2007; Schlacher and Thompson 2008; Herrmann et al. 2009b). Due to the ability to absorb wave energy, the sandy beach ecosystem is one of the most debitable types of dynamic coastlines. The wave energy is used in driving surf-zone water movement, which transports sand offshore during storms and moves it back onshore during calms. Sandy beaches are greatly influenced by the transport of sand not only driven by waves but also by wind in the backshore and dunes. Most of the global sandy beaches are naturally backed by dunes (before the human influence, e.g. constructions in coastal dunes) and interact with them by supplying or receiving immense volumes of sand. Thus, sandy beaches are extremely dynamic environments where both mass of sand and water are always on the move (Komar 1998; Short 1999). Furthermore, the sandy beach ecosystem is characterized by sediment grains, which define the pore space between sediment particles. This socalled interstitial system is important as a habitat for organisms and for the filtration of seawater. The interstitial environment of sandy beaches is mainly controlled by the factors grain size, sorting, shape, packing, porosity, pore size and permeability (McLachlan and Turner 1994). The intertidal of sandy beaches is normally devoid of macroflora so that the microflora and detritus attain an important significance as a food resource for specimens living in this type of environment. The sandy beach flora is usually composed of benthic microalgae and surf-zone phytoplankton, both of which are regularly dominated by diatoms. Although surf clams are commonly the main primary consumers in soft bottom communities and can contribute up to $95 \%$ of the total biomass (McLachlan et al. 1981; Arntz and Fahrbach 1991; Ieno and Bastida 1998), sandy beaches are inhabited by most phyla of invertebrates as interstitial forms or as members of the macrofauna, or both.

The yellow clam Mesodesma mactroides ${ }^{1}$ Reeve, ${ }^{2} 1854$ (Bivalvia: Mesodesmatidae), also known as 'almeja amarilla' in Argentina and Uruguay, is a peculiar species (Parodiz 1942; Stuardo 1964). As one of the most common bivalves of South America (Defeo 1989), it inhabits intertidal Atlantic sandy beaches from tropical $\left(23^{\circ} \mathrm{S}\right.$ Ilha Grande, Rio de Janeiro State, Brazil) to temperate latitudes ( $40^{\circ} \mathrm{S}$ Isla del Jabalí, Province of Buenos Aires, Argentina) (Rios 1994; Fiori and Morsán 2004). Thus, its distributional range covers about $1,800 \mathrm{~km}$ South Brazilian sandy beaches, $22 \mathrm{~km}$ in Uruguay and $375 \mathrm{~km}$ in Argentina. A suspension-feeder, the yellow clam is the only Mesodesma species occurring throughout the Argentinean intertidal (Olivier et al. 1971). It cooccurs in the north of Argentina with the sympatric and numerically dominant surf clam Donax hanleyanus (Herrmann 2009). During the 1940s and 1950s, M. mactroides was an important economic resource in Argentina. A maximum exploitation of 1,079 tonnes was reached in 1953, but the fishery was closed in 1956 following a stock crash (Coscarón 1959) from which the population never recovered. Abundances were decimated further by subsequent mass mortality events in March 1993 due to a red tide incident (Odebrecht et al. 1995), in the 1990s due to an unknown cause (Fiori and Cazzaniga 1999) and most recently as a likely result of heavy metal pollution (Thompson and Sánchez de Bock 2007). Illegal extractions and the impact of tourism may also be contributing factors in the failure of the species to make a recovery (Bastida et al. 1991). Although there are a number of recent studies on populations of $M$. mactroides from Uruguay (e.g., Defeo 1989; Defeo et al. 1986, 1988b, 1991, 1992c; Brazeiro and Defeo 1999; Lima et al. 2000), the last Argentinean study is 40 years old (Olivier et al. 1971). The aim of this study is to estimate contemporary population parameters and production and to make comparisons with data from the historical study. Additionally, this study aims at examining the possible influence of physical and biological factors on the yellow clam growth and to compare observed population parameters with those of other members of the genus from elsewhere.

\footnotetext{
${ }^{1}$ M. mactroides reference specimens were deposited in the collections of the 'Museum für Naturkunde der Humboldt-Universitätzu Berlin' and the 'Museo Argentino de CienciasNaturales-Bernardino Rivadavia' under the reference numbers ZMB/Moll.104643 and MACN-In37513, respectively.

${ }^{2}$ In previous studies, Deshayes 1854 was cited spuriously as the author who first described M. mactroides. However, this description was not published by Deshayes but by his colleague Reeve; thus, the corresponding author of M. mactroides is Reeve 1854 (see Reeve 1854; Deshayes 1855).
} 


\section{Materials and methods}

Study area

This study was carried out at the three south Atlantic beaches Santa Teresita $\left(36^{\circ} 32^{\prime} \mathrm{S}, 56^{\circ} 41^{\prime} \mathrm{W}\right)$, Mar de las Pampas $\left(37^{\circ} 19^{\prime} \mathrm{S}, 57^{\circ} 00^{\prime} \mathrm{W}\right)$ and Faro Querandí $\left(37^{\circ} 29^{\prime} \mathrm{S}\right.$, $7157^{\circ} 07^{\prime} \mathrm{W}$ ) (Fig. 1), whereby we want to underline that M. mactroides was insignificantly abundant at the last two mentioned locations during the entire sampling period. Consequently, the population structure, growth and production of the intertidal yellow clam were studied during alternate spring tides only at Santa Teresita. According to McLachlan's (1980) rating scale for exposure and Short and Wright's (1983) classifications of beach types, Santa Teresita can be classified as sheltered and dissipative (for detailed physical parameters see: Herrmann 2009). This is an open ocean beach receiving continuous wave action and is subject to semidiurnal tides, with a maximum tide range of $1.6 \mathrm{~m}$; spring tides average $1.7 \mathrm{~m}$ and mean neap tides $0.2 \mathrm{~m}$. The sea surface temperature (SST) varies between $11^{\circ} \mathrm{C}$ in winter and $23^{\circ} \mathrm{C}$ in summer. The study site is composed of good-moderate fine sand, with a mean particle diameter of 2.26 phi (Herrmann 2009). The welldrained and oxygenated sandy beach of Santa Teresita is affected by a freshwater seepage and a southward current that brings water masses from the 290-km-long and up to

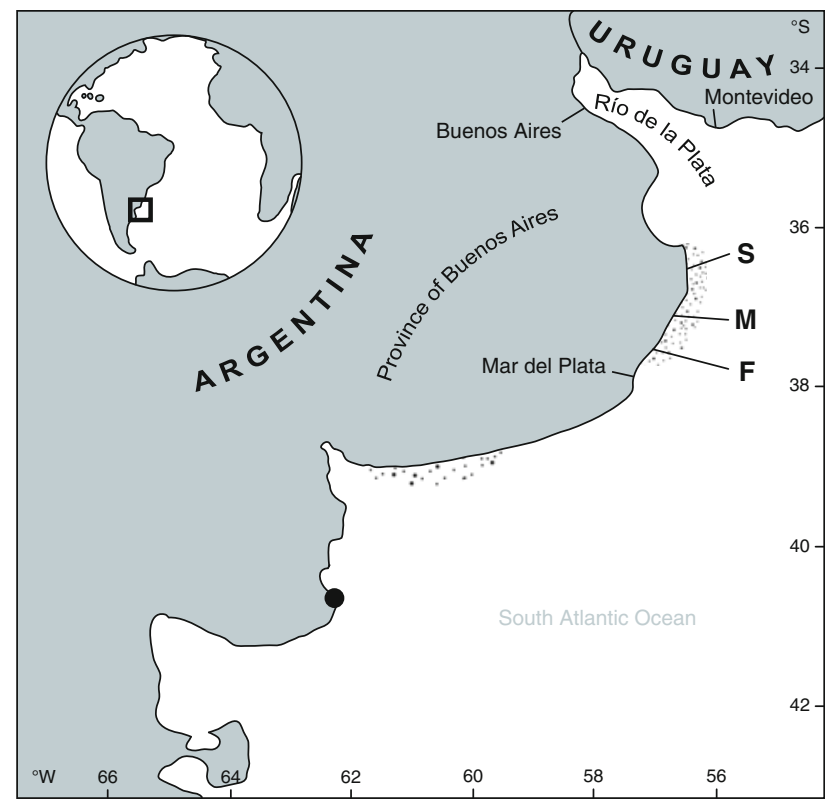

Fig. 1 Map of the three study sites at the Argentinean Atlantic coast: Santa Teresita (S), Mar de las Pampas (M) and Faro Querandí (F). Filled circle indicates the southernmost distribution of $M$. mactroides at Isla del Jabalí. Dotted areas indicate northern and southern sandy beaches of the Province of Buenos Aires where major M. mactroides populations existed in 1953-1956 (Coscarón 1959) 220-km-wide estuary of the Río de la Plata and is thus characterized by a mean salinity of 31 .

Sampling and laboratory procedures

Quantitative sampling of M. mactroides was carried out at monthly intervals from December 2004 to December 2006, using a series of stations located at 4-m intervals along a transect running perpendicular to the shoreline from the spring tide high water mark to the spring tide low water mark. At each station, three replicate sand samples $(40 \times 40 \mathrm{~cm})$ were excavated to $50 \mathrm{~cm}$ depth using a stirring corer and sieved individually on a $1-\mathrm{mm}$ mesh. To obtain monthly length-frequency distributions, the maximum anterior-posterior shell length (apSL) of yellow clams retained on the mesh was measured to the nearest $0.1 \mathrm{~mm}$ using a digital vernier calliper (Mitutoyo, model 500-161U). For biomass analysis, monthly sub samples of 35 specimens were collected and stored in $70 \%$ ethanol. To estimate shell-free wet mass $(S F W M)$, soft tissues were removed and weighed after blotting on filter paper in the laboratory. Samples were subsequently dried to constant mass at $70^{\circ} \mathrm{C}$, weighed again to determine shell-free dry mass $(S F D M)$ and ignited in a muffle furnace at $550^{\circ} \mathrm{C}$ for $5 \mathrm{~h}$ in order to estimate ash-free dry mass $(A F D M)$.

Growth, growth performance, lifespan and mortality

A series of 25 length-frequency distributions provided the basic information for growth estimates. A von Bertalanffy growth function $(V B G F)$ (von Bertalanffy 1938) was fitted to the data using the electronic length-frequency analysis 'ELEFAN I' routine of the FISAT II program package (Gayanilo et al. 2005):

$L_{t}=L_{\infty}\left[1-\mathrm{e}^{\left[-K\left(t-t_{0}\right)+\left(\frac{K C}{2 \pi}\right)\right] \sin 2 \pi\left(t-t_{s}\right)-\left(\frac{K C}{2 \pi}\right) \sin 2 \pi\left(t_{0}-t_{s}\right)}\right]$,

where $L_{t}$ is the apSL (mm) at time $t, L_{\infty}$ is the asymptotic maximum apSL (mm), $K$ (year $\left.{ }^{-1}\right)$ is the curvature parameter, $C$ is a constant defining the degree of seasonal oscillation (ranging from 0 indicating continuous nonoscillating growth, to 1 when growth comes to a complete halt at the 'winter point' $(W P)), t_{0}$ is the theoretical age at zero length (year) and $t_{\mathrm{s}}$ is the initial point of oscillation in relation to $t=0$ and the WP. The different subroutines of ELEFAN I ( $K$-scanning) were used to identify the $V B G F$ that best fitted the monthly size-frequency data, using the $R_{n}$ value as a criterion of fit.

To measure growth performance, the growth index phi prime $\left(\phi^{\prime}\right)$ defined as:

$\phi^{\prime}=2 \log _{10}\left(L_{\infty}\right)-\log _{10} K$

was used. This criterion was chosen because the negative correlation between $K$ and $L_{\infty}$ invalidates comparisons 
based on individual parameters (Pauly and Munro 1984).

Finally, the overall growth performance index

$O G P=\log \left(K\left[L_{\infty}\right]^{3}\right)$,

which represents growth rate at the point of inflexion of the size-growth curve (Pauly 1979), was calculated to compare growth of M. mactroides with other surf clam species.

The theoretical lifespan $\left(t_{\max }\right)$ was estimated by an inverse of the von Bertalanffy growth equation, considering maximum shell length as $95 \%$ of the asymptotic length (Taylor 1958):

$t_{\max }=\frac{\left[\ln L_{95 \%}-\ln \left(L_{\infty}-L_{95 \%}\right)\right]}{K}$,

where $L_{95 \%}$ represents $95 \%$ of the maximum shell length recorded during field sampling.

Total mortality $(Z)$ was calculated for 2005 and 2006 separately from length-converted catch curves (Pauly 1995) yielded by the ELEFAN II routine of the FISAT program (Gayanilo et al. 2005). $Z$ was estimated by:

$\ln (N)=g-Z \cdot t$,

where $N$ is the number of individuals, $g$ is the regression intercept, $Z\left(\right.$ year $\left.^{-1}\right)$ is the unbiased mortality estimate, and $t$ is the estimated age (year) for each cohort (Pauly 1995).

Biomass and production

To compare biomass of $M$. mactroides with values for other species, all published values retrieved were converted to AFDM (according to Brey et al. 1988), whereby a conversion factor of 0.186 ( $S F W M$ to $A F D M$ for ethanol [70\%] preserved $M$. mactroides) was empirically determined. Parameters of the relationship between length and ash-free dry mass $(A F D M)$ of M. mactroides were estimated by regression analysis

$M=a L^{b}$,

where $M$ is the $A F D M(\mathrm{~g}), L$ is the shell length of the size class (mm), and $a$ and $b$ are constants. AFDM was determined for 400 specimens of all size classes sampled between December 2004 and December 2006.

Total annual productivity was calculated for the $M$. mactroides belt at Santa Teresita (January-December 2005 and January-December 2006) using the mass-specific growth rate method (Crisp 1984; Brey 2001) from sizemass relationships, the size-frequency distribution obtained from all pooled samples and the VBGF:

$P=\sum N_{i} M_{i} G_{i}\left(\mathrm{~g} A F D M \mathrm{~m}^{-2}\right.$ year $\left.^{-1}\right)$,

where $N_{i}$ and $M_{i}$ are the average abundance of animals (number $\mathrm{m}^{-2}$ ) and mean individual AFDM in length class $i$, respectively, and $G_{i}$ is the mass-specific growth rate:
$G_{i}=b K\left[\left(\frac{L_{\infty}}{L_{i}}\right)-1\right]\left(\right.$ year $\left.^{-1}\right)$,

where $b$ is the exponent of the size-mass relation, $K, L_{\infty}$ are $V B G F$ parameters and $L_{i}$ is the mean size in class $i$.

Mean annual biomass was estimated as

$\bar{B}=\sum N_{i} M_{i}\left(\mathrm{~g} A F D M \mathrm{~m}^{-2}\right)$,

and annual $P / \bar{B}$ ratios of the $M$. mactroides population were calculated from annual total production $P$ and mean annual biomass $\bar{B}$.

Statistical analysis

Temporal differences of the population abundance and mean $O G P$ were analysed statistically by one-way ANOVA using the software package SPSS version 17.0 (2008). Differences were considered significant at a level of $\alpha=5 \%$ (Zar 1999).

\section{Results}

No M. mactroides populations were discovered south of Santa Teresita during the sampling period. Only a few single individuals were recorded at Mar de las Pampas (August 2005: 31 ind. $\mathrm{m}^{-2}$ ) and Faro Querandí (August 2005: 19 ind. $\mathrm{m}^{-2}$; March, April and October 2005: 6 ind. $\mathrm{m}^{-2}$ and February 2006: 6 ind. $\mathrm{m}^{-2}$ ) meaning that population parameters and production could not be estimated for these two last mentioned areas.

Population structure

Greatest abundance was recorded in May 2005, with $110 \pm 25$ ind. $\mathrm{m}^{-2}$ (mean $\pm \mathrm{SE}$ ) and absolute abundance peaked at 543 ind. $\mathrm{m}^{-2}$ (size class 2-4 mm) in April 2005 (Fig. 2). Distinct cohorts were apparent in the length-frequency distributions obtained (Fig. 3). In both years, a single new cohort was observed during February. New cohorts were tracked for up to 11 months in which they reached apSLs of $27 \mathrm{~mm}$ in 2005 and approximately $35 \mathrm{~mm}$ in 2006 before disappearing, after which new recruits appeared.

Growth, longevity and mortality

During the 25-month study period 3,015 M. mactroides were collected and measured at Santa Teresita: 2,142 ind. in the first year and 873 ind. in the second year. The smallest recorded individual (apSL $2 \mathrm{~mm}$ ) was found in winter (September 2005), and the largest specimen (apSL64 mm) was found in summer (February 2005). The 
Fig. 2 Population abundance of M. mactroides from December 2004 to December 2006 at Santa Teresita. * M. mactroides was not abundant during sampling in January 2006. Error bars: standard error (SE)

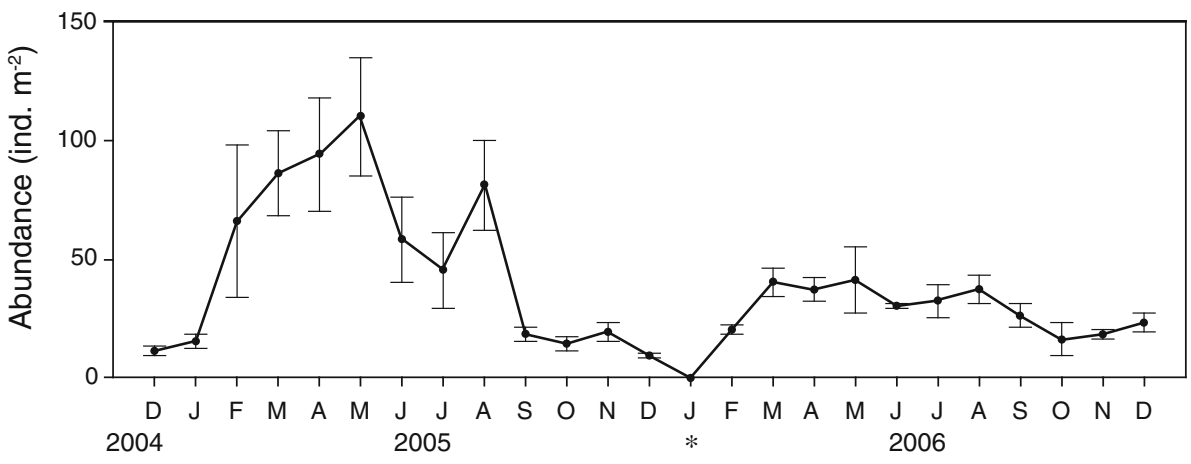

estimated $V B G F$ of the $M$. mactroides population at Santa Teresita with the growth parameter $K=0.47\left(\right.$ year $^{-1}$ ) and $L_{\infty}=85 \mathrm{~mm}(a p S L)$ are shown in Fig. 4. The corresponding $\phi^{\prime}$ index (3.53) and $O G P$ (5.46) are compared with those of Mesodesma growth parameters, calculated from different areas. Parameter $C=0.10$ indicated weak seasonal variation in growth, with lowest growth rates occurring in winter $(W P=0.7 \sim$ mid-August). The calculated lifespan $\left(t_{\max }\right)$ of M. mactroides was 6.19 years, and the instantaneous mortality rate $(Z)$ was 3.01 year $^{-1}$ in 2005 and 2.57 year $^{-1}$ in 2006.

Biomass and production

The observed relationship between length and calculated AFDM of $M$. mactroides $M_{(A F D M)}=\left(9.44 \times 10^{-6}\right) \times$ $L_{(\mathrm{mm})}^{2.83}\left(N=606, r^{2}=0.98\right)$ was used for production estimates.

Annual abundance of $M$. mactroides (mean $\pm \mathrm{SE}$ ) was $48 \pm 13$ ind. $\mathrm{m}^{-2}$ in 2005 and $29 \pm 3$ ind. $\mathrm{m}^{-2}$ in 2006. Within the Mesodesma belt, these abundance values represent an average annual biomass $\bar{B}$ of $0.07 \mathrm{~g} A F D M$ $\mathrm{m}^{-2}$ year $^{-1}$ (2005) and $0.06 \mathrm{~g} \mathrm{AFDM} \mathrm{m}^{-2}$ year $^{-1}$ (2006) (Fig. $5 \mathrm{~b}-\mathrm{c}$ ). Individual production increased to its highest

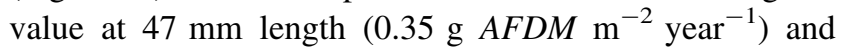
decreased thereafter (Fig. 5a). The distribution of total annual production $P$ and abundance among the size classes are illustrated in Fig. 5b-c. Annual production ranged between 0.12 and $0.19 \mathrm{~g} A F D M \mathrm{~m}^{-2}$ year $^{-1}$, and $P / \bar{B}$ ratios were between 1.84 and 2.93 .

\section{Discussion and conclusion}

Population structure

Comparison of historical data (Olivier et al. 1971) with present situation, both diagrammed in Fig. 3, showed considerable differences in the population structure of $M$. $\mathrm{mac}$ troides. The number of individuals was many times higher in
1968 compared to 2005 (up to 53 times higher in December), suggesting a much smaller reproduction success nowadays during spring time, which represents one of the two spawning seasons per year (Herrmann et al. 2009a). Not merely the number of individuals can be registered as a great difference between the historical population and the recent one, but rather the bivalves in 1968 reached a much higher apSL. Studied individuals from the present work never reached the 'commercial size' of $60 \mathrm{~mm}$ (Coscarón 1959); indeed, only three individuals with apSL of $>60 \mathrm{~mm}$ were recorded in the entirety of the study period. Furthermore, the analysis of Fig. 3 showed up to three cohorts in the past population structure, whereas in the current study it was found only one single cohort of $M$. mactroides. However, since Herrmann et al. (2009b) reported variations in the reproductive biology of the wedge clam $D$. hanleyanus, depending on different beach morphodynamics, it cannot be excluded that also the population structure of $M$. mactroides can be diversified between beaches with contrasting morphodynamics, for which the comparison between populations of M. mactroides from Mar Azul (historically) and Santa Teresita (presently) only can point out a tendency.

Growth and growth performance

The data presented here confirm that $M$. mactroidesis a fastgrowing species $\left(K=0.47 ; \phi^{\prime}=3.4\right)$ and fall in line with estimates from previous studies of Argentinean and Uruguayan populations $\left(K=0.3-0.9 ; \phi^{\prime}=3.3-3.8\right.$; Table 1$)$. However, changes in growth parameters are evident when the recent values (Table 1, no. 1) are compared with those of Olivier et al. (1971) (Table 1, no. 9). In 1968-1970, M. mactroides showed a lower growth constant $(K=0.28$ vs. 0.47), indicating that yellow clam growth was slower four decades ago, but that eventual maximum length was almost even compared to the present $\left(L_{\mathrm{t}(1968-1970)}=\right.$ $\left.84 \mathrm{~mm} ; L_{\mathrm{t}(2005-2006)}=85 \mathrm{~mm}\right)$. Our values are in conformity with estimated maximum shell length of $M$. mactroides from previous studies in Argentina (Olivier et al. 1971: $84 \mathrm{~mm}$ ) and Uruguay (Defeo et al. 1992a: $100 \mathrm{~mm}$ ). 


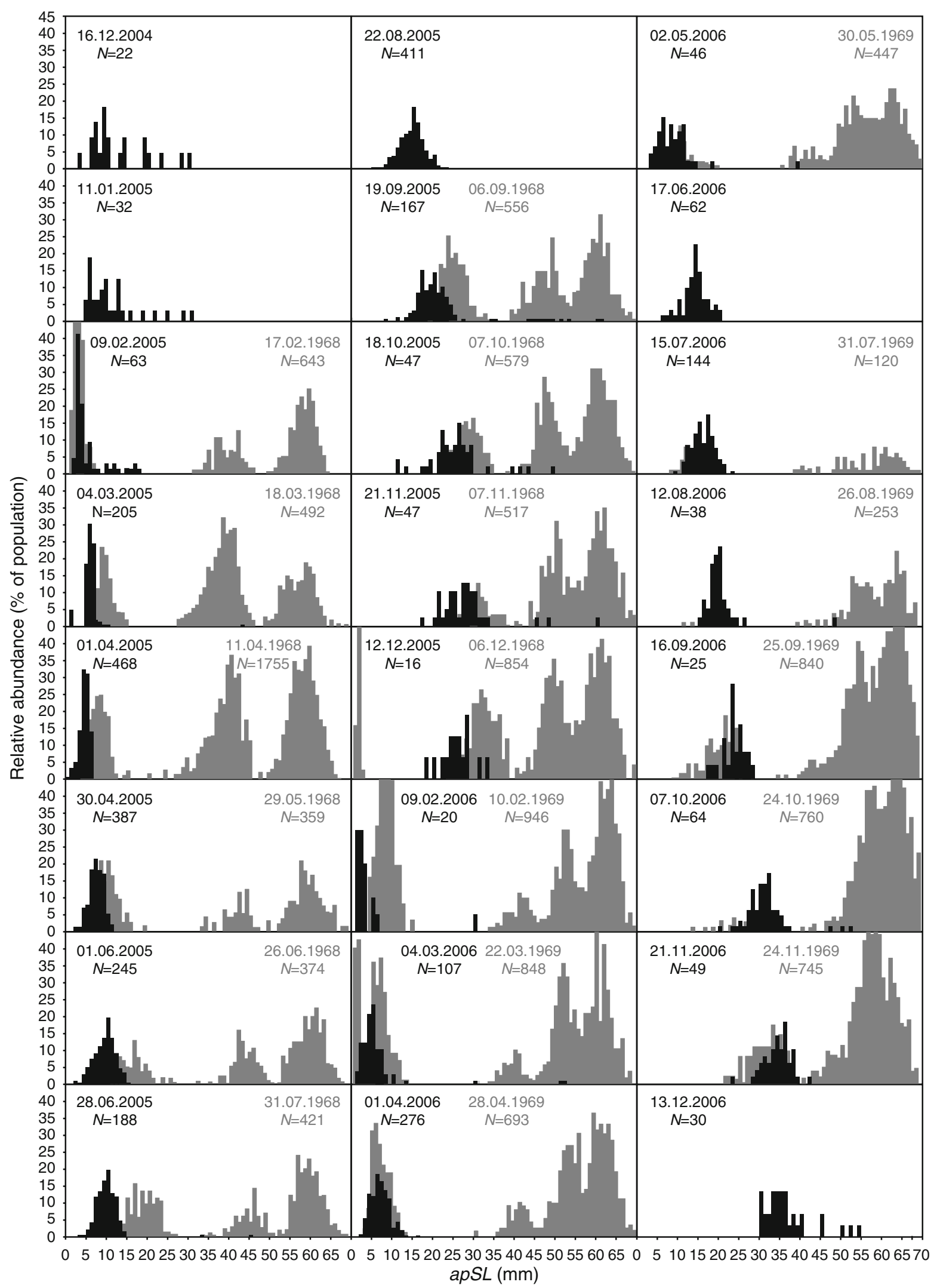

Fig. 3 Monthly length-frequency distribution of M. mactroides collected between December 2004 and December 2006 at Santa Teresita (black histograms) compared with historical data from Olivier et al. (1971) sampled between 1968 and 1969 at Mar Azul (grey histograms) 


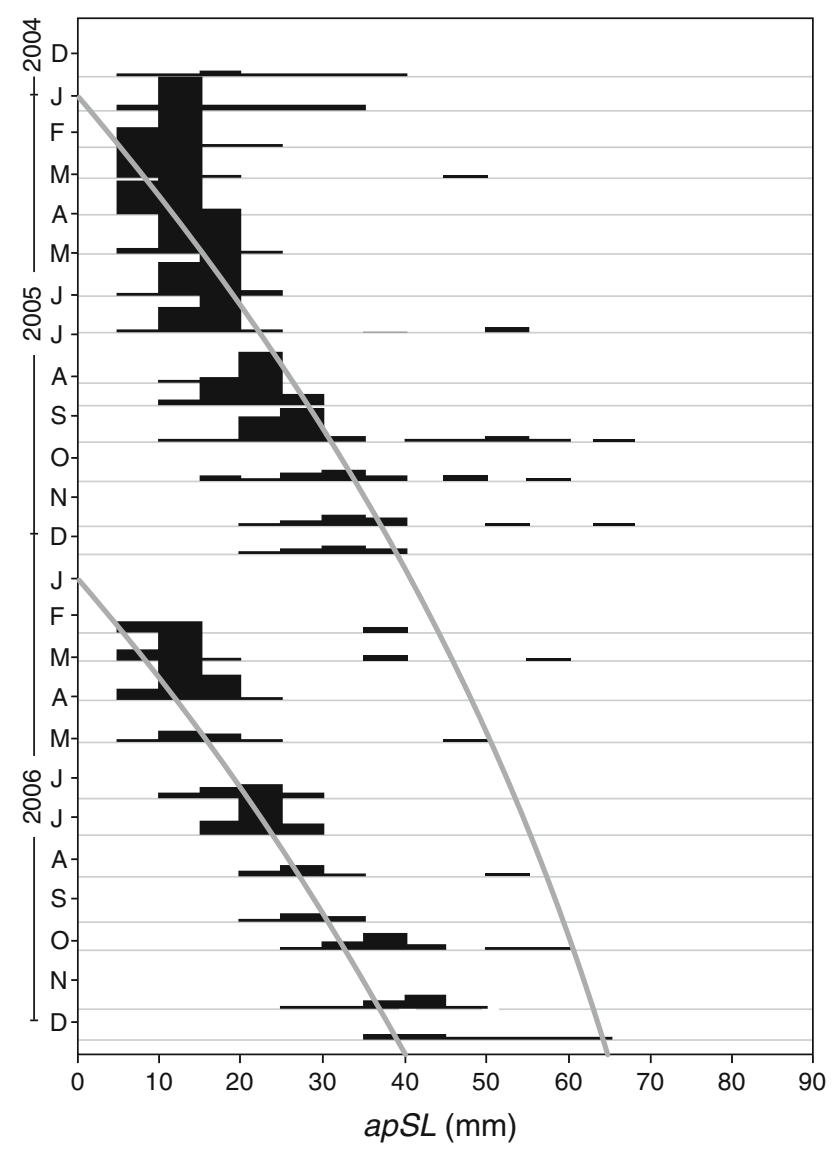

Fig. 4 The VBGF (grey lines) of $M$. mactroideswas estimated with the FISAT program from monthly length-frequency data (black histograms for the period December 2004 to December 2006)

While Defeo et al. (1992c)observed strong seasonal variation $(C=1.0)$ in growth rates for a $M$. mactroides population in Uruguay, the variation documented by Fiori and Morsán (2004) was low ( $C=0.45$ ), and Olivier et al. (1971) recorded no seasonal variations for this species from the Argentinean coast. In support of these latter findings, the present study estimated $C=0.1$.

Nonlinear growth functions such as the $V B G F$ are difficult to compare, and several authors (e.g., Pauly 1979; Munro and Pauly 1983; Moreau et al. 1986; Laudien et al. 2003; Herrmann 2009) have demonstrated the suitability of composite indices of overall growth performance $(O G P)$ for inter- and intraspecific comparisons for various clam species. $O G P$ is proportional to the maximum rate of body mass increase during a lifetime, i.e. mass increase at the inflexion point of the $V B G F$. Few values of maximum body mass can be found in the literature and maximal mass is proportional to $L_{\infty}$. The $O G P$ value of 5.46 (Table 1, no. 1) obtained for M. mactroides in this study conforms with the values of 5.22 (Olivier et al. 1971) and 5.30 (Fiori and Morsán 2004) calculated from data sets of previous studies on Argentinean populations of the same species and also

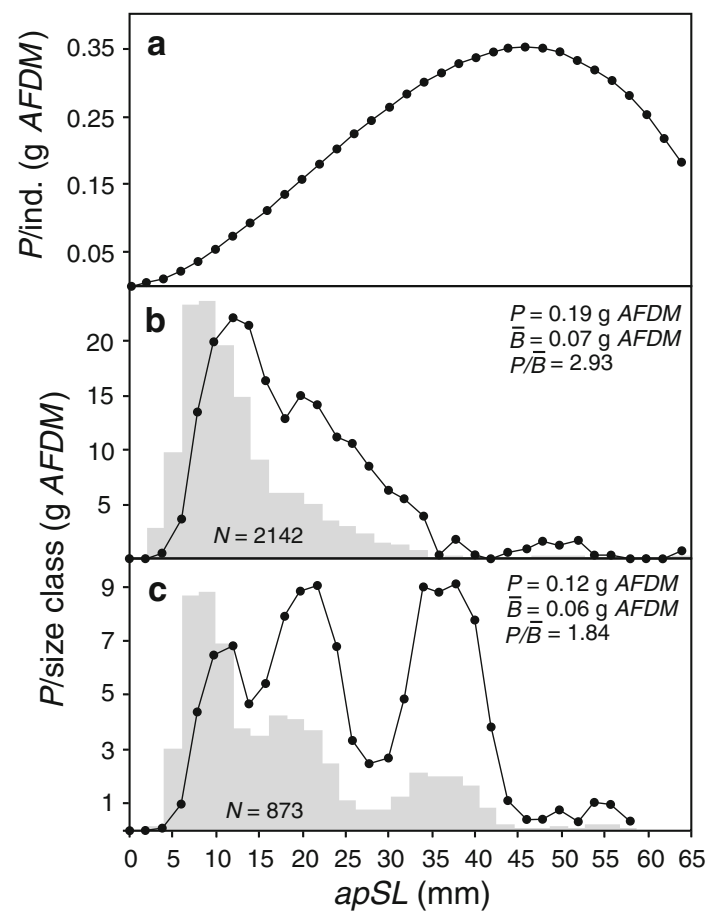

Fig. 5 Distribution of annual somatic individual (a) and population production at Santa Teresita for 2005 (b) and 2006 (c). Mean abundance (grey areas $=100 \%$ ) for the different length classes of M. mactroides is also given

with the value of 5.28 for a population of $M$. donacium from the Peruvian sampled after an El Niño (EN) event (Arntz et al. 1987). It can be assumed that SST and food availability are key factors affecting growth and aspects of population dynamics such as production, reproduction, recruitment and mortality. The relatively high values of $O G P$ from Uruguay (Fig. 6, no. 10-13) and Peru (before and during an EN event, Fig. 6, no. 14-15), suggest a negative correlation with latitude (Fig. 7: $y=6.77-0.04 x$, $r=0.94, P<0.05, N=12$ ). This trend provides support to the latitudinal gradient hypothesis of marine invertebrates (Defeo and Cardoso 2002), which predicts a positive correlation between body size and latitude: populations from subtropical beaches exhibited higher growth and mortality rates and shorter lifespans than those of temperate beaches. However, this observation would be better understood if growth studies on several populations could be linked to quantitative and qualitative data regarding phytoplankton. Results compiled from several studies of two different Mesodesma species confirmed the hypothesis of Laudien et al. (2003) that $O G P$ is habitatspecific (Fig. 6). OGP is lowest (5.22-5.81, group A) for $M$. mactroides-populating temperate regions and highest (6.33, group B) for $M$. donacium of an upwelling area. Mean $O G P$ s of the two groups were significantly different (ANOVA, $F_{1,14}=21.716, P<0.05$ ). Climate anomalies 


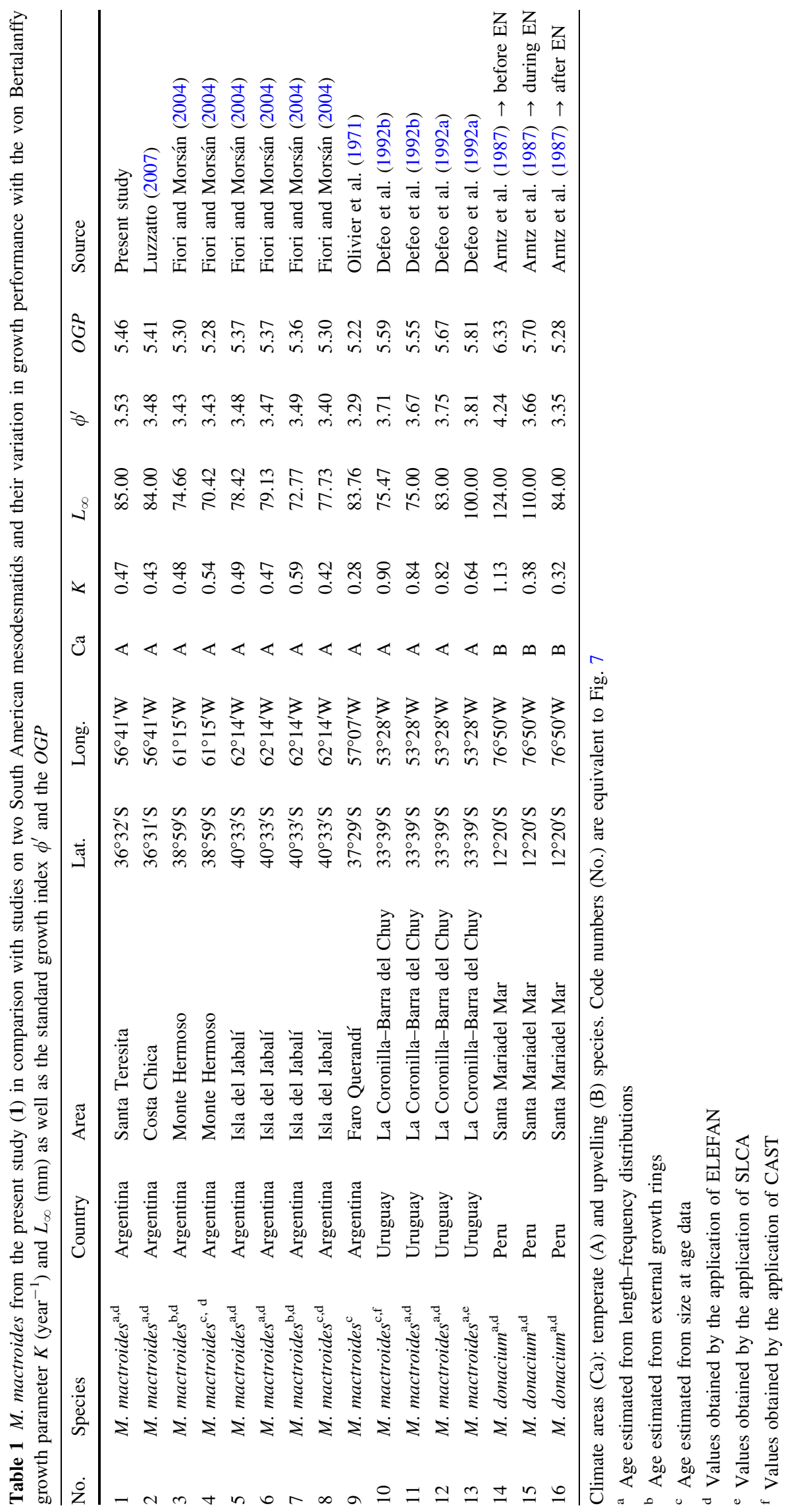




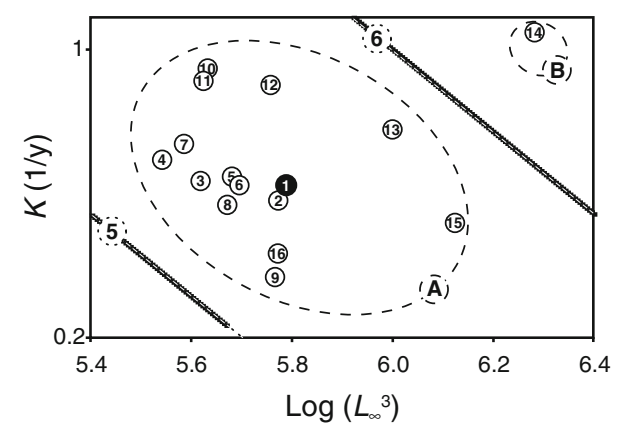

Fig. 6 Auximetric grid comparing the $O G P$ of the Argentinean $M$. mactroides from the present study (()) with several Mesodesma populations from different areas (white circles). Plot indicates two groups: temperate $(A)$ and upwelling species $(B)$, indicated by dashed contours. Dotted diagonal lines show equal values of OGP (numbers in dotted circles). For keys and data sources, see Table 1

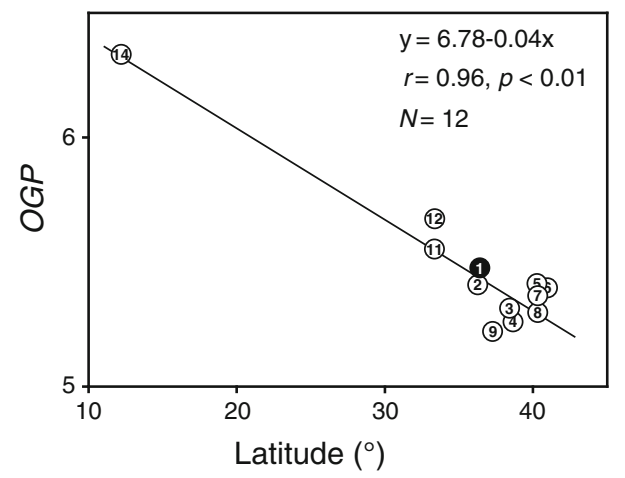

Fig. 7 OGP of M. mactroides from the present study (0) estimated from length-frequency data and obtained from ELEFAN, compared with several Mesodesma populations from different latitudes. For comparing values, see Table 1

may be detected with the help of the auximetric grid, as indicated by the lower $O G P$ for the upwelling surf clam M. donacium sampled in Peru during and shortly after EN (1982/1983, Fig. 6, no. 15-16) compared to data from normal upwelling years (Fig. 6, no. 14) (Arntz et al. 1987).

\section{Biomass and production}

Annual intertidal biomass of the M. mactroides population at Santa Teresita ranged between 0.06 and $0.07 \mathrm{~g} \mathrm{AFDM}$ $\mathrm{m}^{-2}$ year $^{-1}$ and production varied between 0.12 and $0.19 \mathrm{~g}$ $A F D M \mathrm{~m}^{-2}$ year $^{-1}$. Unfortunately, comparable information on the species from elsewhere is very scarce. To the best of our knowledge, no study of this kind has been carried out in Brazil. Defeo (1985) estimated a biomass of $133 \mathrm{~g}$ AFDM $\mathrm{m}^{-2}$ (converted from $S F W M$ values published) for the Uruguayan M. mactroides population, while four decades ago the biomass of Argentinean M. mactroides was estimated at $323 \mathrm{~g} A F D M \mathrm{~m}^{-2}$ (Olivier et al. 1971, calculated from published $S F W M$ data). Thus, the once-prominent role of this primary consumer in the ecosystem appears to be reduced. The individuals observed during the present study were small compared to the records of Olivier et al. (1971), in which individuals of commercial size $(>60 \mathrm{~mm})$ were found throughout the year. The reason may be a change in environmental conditions, which has impacted directly on food supply. Biomass data ranging from 141 to $546 \mathrm{~g}$ $A F D M \mathrm{~m}^{-2}$ year $^{-1}$ for the similar-sized surf clam $D$. serra, which occupies a similar ecological position in the Benguela-upwelling system (Laudien et al. 2003) lead us to hypothesize that environmental conditions off Argentina may have been more favourable with regard to major primary production four decades ago. Indeed, changes in the environmental conditions of the Argentinean coast are implicated in a study of historical SSTs (Bava et al. 1999). The authors reported that EN 1992 evoked negative SST anomalies throughout the south western Atlantic. However, a detailed understanding of the collapse of the Argentinean M. mactroides population would require analysis of further historical climate and phytoplankton data.

\section{Lifespan and mortality}

There is some controversy concerning longevity estimates for M. mactroides. Olivier et al. (1971) estimated a maximum age of $\sim 8$ years for the Argentinean yellow clam population, using length-frequency analysis. In contrast, Defeo et al. (1988a) suggested a lifespan of $\sim 3.5$ years for Uruguayan Mesodesma populations, derived by the interpretation of shell growth rings. Length-frequency analysis of the current data set yields a lifespan of $\sim 6$ years, an intermediate estimate within the range of the aforementioned extremes.

The instantaneous mortality rate $(Z)$ for the Argentinean $M$. mactroides was higher in the present study (2.57-3.01 year $\left.{ }^{-1}\right)$ compared to calculations $\left(0.85\right.$ year $\left.^{-1}\right)$ from Olivier et al. (1971), but fits well with mortality rates for the same species from Uruguayan beaches (Defeo et al. 1992c: 2.26-2.91 year ${ }^{-1}$ ). Arntz et al. (1987) also found similar mortality rates $\left(Z=2.5\right.$ year $\left.^{-1}\right)$ for the closely related $M$. donacium inhabiting Peruvian sandy beaches. Found differences in mortality rates indicate that the Argentinean M. mactroides population this day is much more stressed than 40 years ago. Factors inducing this stress are possibly engendered by ecological (e.g. mass mortality events) and environmental aspects (e.g. changing beach morphodynamics by human impacts).

Ecological aspects

The carnivorous gastropod Olivancillaria vesica auricularia, a known predator of surf clams in Brazilian sandy 
beaches (Marcus and Marcus 1959; Gianuca 1985; RochaBarreira de Almeida 2002), also attacks M. mactroides and D. hanleyanus at Santa Teresita (V. S. Teso, pers. communication). Predator-prey relationship tests revealed escape behaviour in both clams, when approached by the snail. Surf clams sought refuge even without direct contact, excavating themselves within $10 \mathrm{~s}$ in order to escape with the next wave (M. Herrmann, unpublished data).

From previous investigations (e.g., Olivier et al. 1971; Penchaszadeh and Olivier 1975; Bastida et al. 1991), it is well-known that intertidal sandy beach communities of northern Argentina were inhabited by large co-existing populations of the surf clams M. mactroides and D. hanleyanus. However, the significant negative correlation between the abundances of $D$. hanleyanus (data taken from Herrmann 2009) and M. mactroides (Fig. 8) at Santa Teresita in 2005 suggests that the timing of abundance peaks of $D$. hanleyanus may be related to periods of low M. mactroides abundance. Penchaszadeh and Olivier (1975), Dadon (2005) and Defeo and de Alava (1995) observed similar inverse correlations between $D$. hanleyanus and M. mactroides abundance on Argentinean and Uruguayan beaches. Furthermore, surf clam populations from the Peruvian Pacific coast also showed the same relationship, and abundances of Emerita analoga and D. marincovichi (formerly D. peruvianus) increased coincidentally with the collapse of $M$. donacium populations (Penchaszadeh 1971; Tarazona et al. 1985; Arntz et al. 1987). Defeo and de Alava (1995) hypothesized that interspecific competition for space and food might explain the relationship between $D$. hanleyanus and $M$. mactroides. Olivier et al. (1971) supported this by describing overlapping trophic niches of the two species and predicted that limited food availability might soon impact on M. mactroides. However, results in the present study suggest that the two surf clam species do not compete for resources at Santa Teresita. The fact that abundances of $D$. hanleyanus and $M$. mactroides populations were previously much higher than at present (Olivier et al. 1971; Penchaszadeh

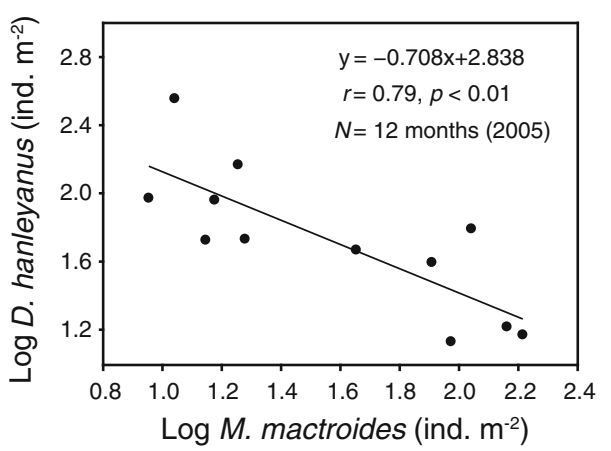

Fig. 8 M. mactroides $-D$. hanleyanus linear correlation of abundances $\left(\log\right.$ ind. $\mathrm{m}^{-2}$ ) from 2005 at Santa Teresita

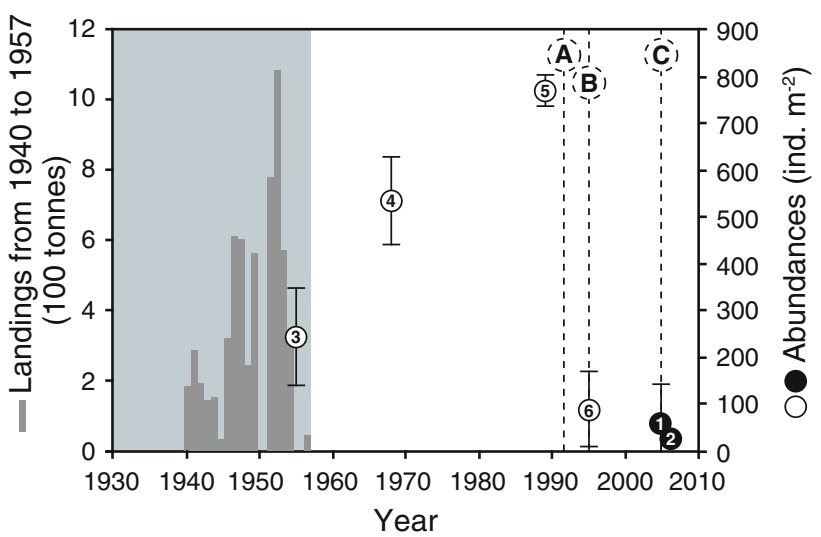

Fig. 9 Population trends in the Argentinean surf clam M. mactroides: mean abundances from the present study $(\mathbf{1}: 2005 ; 2$ : 2006) compared with historical records (3: Coscarón 1959; 4: Olivier et al. 1971; 5: Bastida et al. 1991; 6: Mabragaña 1997) and landing data (histogram: Coscarón 1959). (A) indicates mass mortality of M. mactroides in South America (in March 1993: Odebrecht et al. 1995), (B) and (C) unexplained mass mortality events in Argentina (in November 1995: Fiori and Cazzaniga 1999; in September 2004: Thompson and Sánchez de Bock 2007, respectively). Grey area shows the period when $M$. mactroides was commercially fished, the white area is the period when the clam fishery was closed

and Olivier 1975) makes food availability an even less likely limiting factor in the current scenario.

This said, the balance between these two species appears to have been disturbed following mass mortality events affecting M. mactroides in March 1993 (Odebrecht et al. 1995), November 1995 (Fiori and Cazzaniga 1999) and September 2004 (Thompson and Sánchez de Bock 2007) (Fig. 9). D. hanleyanus, which was not affected by the mass mortality events, took over immediately as the dominant species, but failed to reach the former abundance of M. mactroides. Similar changes in the structure of Peruvian shallow sandy beach communities have been ascribed to EN. Arntz et al. (1987) observed that D. marincovichi (formerly D. peruvianus) prevailed over M. donacium immediately after EN but, like Argentinean $D$. hanleyanus, never matched the abundance of the previously dominant $M$. donacium.

Environmental aspects

Another hypothesis explaining the recent dominance of D. hanleyanus over M. mactroides is a change in granulometry. Penchaszadeh and Olivier (1975) reported that sediment characteristics are principle factors in the distribution of surf clams. Olivier et al. (1971) also described substratum sensitivity in $M$. mactroides, although the clams are able to penetrate into sediments with a wide spectrum of grain sizes. The present study found $M$. mactroides almost exclusively at the fine sand locality Santa Teresita 
where mean grain size was $0.21 \mathrm{~mm}$ (results from granulometric analysis are given in Herrmann 2009).

The present study found no evidence for along-shore migration in $M$. mactroides, although abundances are seen to vary considerably a given location. Additional random sampling south and east of the transect did not reveal greater abundances than those recorded at the monthly stations. Further random sampling with a dive corer (Rumohr and Arntz 1982) in the highly dynamic wavebreaking zone confirmed that unlike Peruvian Donax populations $D$. hanleyanus did not extend into the surf zone.

Acknowledgments This work is part of the doctoral thesis of Marko Herrmann, partly supported by 'DeutscherAkademischerAustauschdienst' (DAAD) and by the University of Bremen. The authors thank Sonia Cabrera, Maria Eugenia Segade Enrique, Juan Pablo Livore, Soledad Zabalaand and my wife Sandra Noir for field assistance. Thanks are also expressed to all Argentinean colleagues from the laboratory 19 at the 'Facultad de Ciencias Exactas y Naturales' (UBA) and from the laboratory 80 at the 'MuseoArgentino de CienciasNaturales-Bernardino Rivadavia' (MACN). Finally, we thank Amy-Jane Beer for English editing.

\section{References}

Arntz WE, Fahrbach E (1991) El Niño-Klimaexperiment der Natur: Die physikalischen Ursachen und biologischen Folgen. Birkhäuser, Basel, Bosten, Berlin, p 264

Arntz WE, Brey T, Tarazona J, Robles A (1987) Changes in the structure of a shallow sandy-beach community in Peru during an El Niño event. S Afr J Mar Sci 5:645-658

Bascom WN (1964) Waves and beaches, the dynamics of the Ocean surface. Anchor Books, Garden City, New York, p 267

Bastida RO, Roux A, Bremec C, Gerpe M, Sorensen M (1991) Estructura poblacional de la almeja amarilla (Mesodesma mactroides) durante el verano de 1989 en la Provincia de Buenos Aires, Argentina. Frente Marit 9A:83-92

Bava J, Gagliardini DA, Lasta CA, Pujol GG (1999) Análisis preliminar de datos de temperatura superficial del mar obtenidos mediante información histórica NOAA-AVHRR para su correlación con bases de datos oceanográficos y pesqueros. XIV Simposio Científico-Tecnol de la ComTéc Mixta del Frente Marítimo, 1999, Montevideo, Uruguay, pp 1-15

Brazeiro A (2005) Geomorphology induces life history changes in invertebrates of sandy beaches: the case of the mole crab Emerita analoga in Chile. J Mar Biol Assoc UK 85:113-120

Brazeiro A, Defeo O (1999) Effects of harvesting and density dependence on the demography of sandy beach populations: the yellow clam Mesodesma mactroides of Uruguay. Mar Ecol ProgSer 182:127-135

Brey T (2001) Population dynamics in benthic invertebrates. A virtual handbook. Version 01.2. Alfred Wegener Institute for Polar and Marine Research, Germany. http://www.thomas-brey.de/science/ virtualhandbook/

Brey T, Rumohr H, Ankar S (1988) Energy content of macrobenthic invertebrates: general conversion factors from weight to energy. J Exp Mar Biol Ecol 117:271-278

Calliari LJ, Klein AHF, Barros FCR (1996) Beach differentiation along the Rio Grande do Sul coastline (Soutern Brazil). Rev Chil Hist Nat 69:485-493
Celentano E, Defeo O (2006) Habitat harshness and morphodynamics: life history traits of the mole crab Emerita brasiliensis in Uruguayan sandy beaches. Mar Biol 149:1453-1461

CIESIN (2000) Percent of the population living within 100 kilometers from the coast is derived from the Center for International Earth Science Information Network (CIESIN), World Resources Institute, and International Food Policy Research Institute, "Gridded Population of the World, Version 2 alpha". Columbia University, Palisades, NY. http://sedac.ciesin.org

Coscarón S (1959) La almeja amarilla (Mesodesma (T.) mactroides Deshayes) de la costa de la Provincia de Buenos Aires. Dir Agrop Publ Tec 1:66

Crisp DJ (1984) Energy flow measurements. In: Holme NA, McIntyre AD (eds) Methods for the study of marine benthos. Blackwell Scientific Publications, Oxford, IBP Handbook no. 16, pp 284-372

Dadon JR (2005) Changes in the intertidal community structure after a mass mortality event in sandy beaches of Argentina. Contrib Zool 74:27-39

de la Huz R, Lastra M, López J (2002) The influence of sediment grain size on burrowing, growth and metabolism of Donax trunculus L. (Bivalvia: Donacidae). J Sea Res 47:85-95

Defeo O (1985) Aspectos biocenológicos y de dinámica de la población de "almeja amarilla", Mesodesma mactroides (Deshayes, 1854) en la zona de la Barra del Chuy, Dpto, de Rocha, Uruguay. I Biocenología 2:50-75

Defeo O (1989) Development and management of artisanal fishery for yellow clam Mesodesma mactroides in Uruguay. Fishbyte 7:21-25

Defeo O (1996) Experimental management of an exploited sandy beach bivalve population. Rev Chil Hist Nat 69:605-614

Defeo O (1998) Testing hypotheses on recruitment, growth, and mortality in exploited bivalves: an experimental perspective. Can Spec Publ Fish Aquat Sci 125:257-264

Defeo O, Cardoso RS (2002) Macroecology of population dynamics and life history traits of the mole crab Emerita brasiliensis in Atlantic sandy beaches of South America. Mar Ecol Prog Ser 239:169-179

Defeo O, de Alava A (1995) Effects of human activities on long-term trends in sandy beach populations: the wedge clam Donax hanleyanus in Uruguay. Mar Ecol Prog Ser 123:73-82

Defeo O, Martínez G (2003) The habitat harshness hypothesis revisited: life history of the isopod Excirolana braziliensis in sandy beaches with contrasting morphodynamics. J Mar Biol Assoc UK 83:331-340

Defeo O, Layerle C, Masello A (1986) Spatial and temporal structure of the yellow clam Mesodesma mactroides (Deshayes 1854) in Uruguay. Medio Ambiente 8:48-57

Defeo O, Masello A, Layerle C (1988a) Consideraciones metodológicas para el estudio del crecimiento en moluscos bivalvos. Inf Unesco Cienc Mar 47:135-148

Defeo O, Rey M, Cascudo J (1988b) Estimaciones de stock del recurso almeja amarilla (Mesodesma mactroides) en base al análisis de cohortes (Pope, 1972). Publ Com Téc Mix Fr Mar 4:41-54

Defeo O, Seijo JC, Euan J, Liceaga M (1991) Dinámica espacial del esfuerzo pesquero en una pesquería artesanal de la costa Atlántica Uruguaya. Invest Pesq (Chile) 36:17-25

Defeo O, Arreguín-Sánchez F, Sánchez J (1992a) Growth study of the yellow clam Mesodesma mactroides: a comparative analysis of three length-based methods. Sci Mar 56:53-59

Defeo O, Jaramillo E, Lyonnet A (1992b) Community structure and intertidal zonation of the macroinfauna on the Atlantic coast of Uruguay. J Coast Res 8:830-839

Defeo O, Ortiz E, Castilla JC (1992c) Growth, mortality and recruitment of the yellow clam Mesodesma mactroides on Uruguayan beaches. Mar Biol 114:429-437 
Delgado E, Defeo O (2007) Tisular and population level responses to habitat harshness in sandy beaches: the reproductive strategy of Donax hanleyanus. Mar Biol 152:919-927

Deshayes MGP (1855) Descriptions of new shells from the collection of Hugh Cuming. Esq Proc Zool Soc Lond 22:317-371

Fiori SM, Cazzaniga NJ (1999) Mass mortality of the yellow clam, Mesodesma mactroides (Bivalvia: Mactracea) in MonteHermoso beach, Argentina. Biol Conserv 89:305-309

Fiori SM, Morsán EM (2004) Age and individual growth of Mesodesma mactroides (Bivalvia) in the southernmost range of its distribution. J Mar Sci 61:1253-1259

Gayanilo FC Jr, Sparre P, Pauly D (2005) FAO-ICLARM stock assessment tools II (FiSAT II). User's guide. FAO computerized information series (Fisheries). No. 8, Revised version. Rome, FAO 2005, $168 \mathrm{p}$

Gianuca NM (1985) The ecology of a sandy beach in Southern Brazil. D.Sc. thesis, University of Southampton, $330 \mathrm{p}$

Gómez J, Defeo O (1999) Lifehistory of the sandhopper Pseudorchestoidea brasiliensis (Amphipoda) in sandy beaches with contrasting morphodynamics. Mar Ecol Prog Ser 182:209-220

Herrmann M (2009) Population dynamics of the surf clams Donax hanleyanus and Mesodesma mactroides from open-Atlantic beaches off Argentina. Rep Pol Mar Res 585:235

Herrmann M, Alfaya JEF, Lepore ML, Penchaszadeh PE, Laudien J (2009a) Reproductive cycle and gonad development of the Northern Argentinean Mesodesma mactroides (Bivalvia: Mesodesmatidae). Helg Mar Res 63:207-218

Herrmann M, Rocha-Barreira de Almeida C, Arntz WE, Laudien J, Penchaszadeh PE (2009b) Testing the habitat harshness hypothesis: reproductive biology of the wedge clam Donax hanleyanus (Bivalvia: Donacidae) on three Argentinean sandy beaches with contrasting morphodynamics. J Moll Stud 76:33-47

Ieno EN, Bastida RO (1998) Spatial and temporal patterns in coastal macrobenthos of Samborombon Bay, Argentina: a case study of very low diversity. Estuaries 21:690-699

Jaramillo E, Duarte C, Contreras H (2000) Sandy beach macroinfauna from the coast of Ancud, Isla de Chiloe, Southern Chile. Rev Chil Hist Nat 73:771-786

Komar PD (1998) Beach processes and sedimentation, 2nd edn. Prentice-Hall, Nwe Jersey

Laudien J, Brey T, Arntz WE (2003) Population structure, growth and production of the surf clam Donax serra (Bivalvia, Donacidae) on two Namibian sandy beaches. Estuar Coast Shelf Sci 58S:105-115

Lima M, Brazeiro A, Defeo O (2000) Population dynamics of the yellow clam Mesodesma mactroides: recruitment variability, density-dependence and stochastic processes. J Exp Mar Biol Ecol 207:97-108

Luzzatto DC (2007) Dinámica poblacional de la almeja amarilla (Mesodesma mactroides) y del berberecho (Donax hanleyanus) en intermareales de playas arenosas del Nordeste de la Provincia de Buenos Aires. Ph.D. thesis, Universidad de Buenos Aires, Facultad de Ciencias Exactas y Naturales, 186 p

Mabragaña E (1997) Ecological studies of the yellow clam Mesodesma mactroides. Present situation of the resource in the north of Buenos Aires Province (Argentina) and recommendations for management. Diploma thesis, Facultad de Ciencias Exactas y Naturales, Mar del Plata (Argentina), $57 \mathrm{p}$

Marcus E, Marcus E (1959) Studies on Olividae. BolmFac Filos CiêncUniv São Paulo (Zoologia) 22:100-188

McLachlan A (1980) The definition of sandy beaches in relation to exposure: a simple rating system. S Afr J Mar Sci 76:137-138

McLachlan A, Brown AC (2006) The ecology of sandy shores. Elsevier, Amsterdam, p 373

McLachlan A, Turner I (1994) The interstitial environment of sandy beaches. Mar Ecol 15:177-212
McLachlan A, Erasmus T, Dye AH, Woolridge T, Van der Horst G, Rossouw G, Lasiak TA, McGwynne LE (1981) Sand beach energetics: an ecosystem approach towards a high energy interface. Estuar Coast Shelf Sci 13:11-25

McLachlan A, Jaramillo E, Defeo O, Dugan J, de Ruyck A, Coetzee P (1995) Adaptions of bivalves to different beach types. J Exp Mar Biol Ecol 187:147-160

McLachlan A, de Ruyck A, Hacking N (1996) Community structure on sandy beaches: patterns of richness and zonation in relation to tide range and latitude. Rev Chil Hist Nat 69:451-467

Moreau J, Bambino C, Pauly D (1986) Indices of overall growth performance of 100 tilapia (Cichlidae) populations. In: Maclean JL, Dizon LB, Hosillos LV (eds) The first Asian fisheries forum. Asian Fisheries Society, Manila, pp 201-206

Munro JL, Pauly D (1983) A simple method for comparing the growth of fishes and invertebrates. Fishbyte 1:5-6

Nel R, McLachlan A, Winter DPE (2001) The effect of grain size on the burrowing of two Donax species. J Exp Mar Biol Ecol 265:219-238

Odebrecht C, Rörig L, Gracia VT, Abreu PC (1995) Shellfish mortality and red tide event in southern Brazil. In: Lassus P (ed) Harmful marine algal blooms. Springer, New York, pp 213-218

Olivier SR, Capezzani D, Carreto J, Christiansen H, Moreno V, de Moreno JA, Penchaszadeh PE (1971) Estructura de la Comunidad, Dinámica de la Población y Biología de la Almeja Amarilla (Mesodesma mactroides) en Mar Azul. Proy Des Pesq FAO 27:1-90

Parodiz JJ (1942) Transgressiones oceánicas y fauna del Mar Epicontinental Argentino. Rev GeográfAmer 18:203-211

Pauly D (1979) Gill size and temperature as governing factors in fish growth: a generalization of the von Bertalanffy's growth formula. BerInst Meeres Univ Kiel 63:1-156

Pauly D (1995) Comparison of age structure and length-converted catch curves of brown trout Salmotrutta in two French rivers. Fish Res 22:197-204

Pauly D, Munro JL (1984) Once more on the comparison of growth in fish and invertebrates. Fishbyte 2:21

Penchaszadeh PE (1971) Estudios sobre el mejillón (Mytilusplatensisd'Orb.) en explotación comercial del sector bonaerense, Mar Argentino. I. Reproducción, crecimiento y estructura de la población. Carpas 12:1-15

Penchaszadeh PE, Olivier SR (1975) Ecología de una población de 'berberecho' (Donax hanleyanus) en Villa Gesell, Argentina. Malacologia 15:133-146

Reeve LA (1854) Monograph of the genus Donax. ConchologiaIconica 8: pls. 1-9

Ricciardi A, Bourget E (1999) Global patterns of macroinvertebrate biomass in marine intertidal communities. Mar Ecol Prog Ser $185: 21-35$

Rios EC (1994) Seashells of Brazil, 2nd edn. Editora da Fundação Universidade de Rio Grande, $481 \mathrm{p}$

Rocha-Barreira de Almeida C (2002) Feeding behavior of Olivancillariavesicaauricularia (Lamarck, 1810) (Mollusca, Olividae). Thalassas 18:83-89

Rumohr H, Arntz WE (1982) The "Benthosgarten"—a new approach for the study of soft bottom communities. Rep Mar Res 29:225-238

Schlacher TA, Thompson LMC (2008) Physical impacts caused by off-read vehicles to sandy beaches: spatial quantification of car tracks on an Australian Barrier Island. J Coast Res 24:234-242

Short AD (1999) Handbook of beach and shoreface morphodynamics. John Wiley, London, p 392

Short AD, Wright LD (1983) Physical variability of sandy beaches. In: McLachlan A, Erasmus T (eds) Sandy beaches as ecosystems. Dr. W. Junk Publishers, The Hague, The Netherlands, pp 133-144 
Souza JRB, Gianuca NM (1995) Zonation and seasonal variation of the intertidal macrofauna on a sandy beach of Parana State, Brazil. Sci Mar (Barc) 59:103-111

SPSS (2008) Statistical package for the social sciences, version 17.0. SPSS inc, Chicago, Illinois

Stuardo BJ (1964) Distribución de los moluscos marinos litorales en Latinoamérica. BolInst Biol Mar, Mar del Plata 7:79-91

Tarazona J, Arntz WE, Canahuire E, Ayala Z, Robles A (1985) Modificaciones producidas durante "El Niño" en la infauna bentónica de áreas someras del ecosistema de afloramiento peruano. In: Arntz WE, Landa A, Tarazona J (eds) "El Niño", su Impacto en la Fauna Marina. BolnInst Mar Perú-Callao, Spec Issue, Proceedings of the Ninth Latin American Congress of Zoology, Arequipa, Perú, October 1983, 55-63
Taylor CC (1958) Cod growth and temperature. J Cons Int Explor Mer 23:366-370

Thompson GA, Sánchez de Bock MF (2007) Mortandad masiva de Mesodesma mactroides (Bivalvia: Mactracea) en el partido de la costa, Buenos Aires, Argentina, en septiembre 2004. Atlântica, Rio Grande 29:115-119

Veloso VG, Cardoso RS (2001) Effect of morphodynamics on the spatial and temporal variation of macrofauna on three sandy beaches, Rio de Janeiro State, Brazil. J Mar Biol Assoc UK 81:369-375

von Bertalanffy L (1938) A quantitative theory of organic growth. Hum Biol 10:181-213

Zar JH (1999) Biostatistical analysis, 4th edn. Prentice-Hall Inc, Upper Saddle River, p 663 